\title{
Should I Trust Social Media? How Media Credibility and Language Affect False Memory
}

\author{
Dewi Maulina ${ }^{1}$ Ishaq Mahmudil Hakim², Ladayna Nurul Arasy ${ }^{3}$, Marsa Dhiya \\ Millatina ${ }^{4}$, Ermanda Saskia Siregar ${ }^{5}$ \\ 1,2,3,4,5Faculty of Psychology, Universitas Indonesia
}

Submitted 20 February 2020 Accepted 3 September 2020 Published 23 December 2020

\begin{abstract}
This study examined the influence of credibility and language in Internet-based media on false memory. A randomized factorial 2 (media credibility) $\times 2$ (language) experimental design was conducted with 106 college students. The two groups of media credibility consisted of social media (LINE) and non-social media (detik.com), while media language consisted of formal and informal language. A confidence test was used to measure false memory. A two-factor ANOVA showed that media credibility significantly affects false memory. Participants in the detik.com group were more confident in the information received and had greater false memory than the LINE group. However, no significant effect of language was found, and no significant interaction effect between media credibility and language on false memory was found. This study suggests that individuals should be cautious when reading information on non-social media platforms, as individuals tend to place more confidence on the source, leading to greater false memory.
\end{abstract}

Keywords: false memory; media credibility; misinformation effect; language; social media

Internet usage continues to increase, including in Indonesia. In general, people use the Internet for obtaining information, self-development, shopping, entertainment, social interaction, and gaming (Van Deursen \& Van Dijk, 2013). Based on a survey conducted by the Association of Indonesian Internet Service Providers (Asosiasi Penyelenggara Jasa Internet Indonesia, or APJIII) in 2014, the use of social media and the seeking of latest news were found to be two of the four primary online activities of Indonesian internet users. Social media platforms such as Whatsapp, LINE, Facebook, and Twitter,

\footnotetext{
${ }^{1}$ Address for correspondence:

dewi.maulina@ui.ac.id
}

as well as online news portals like detik.com, Kompas.com, and Tribunnews.com, are the most used sites on the Internet (Kemp, 2020).

For Indonesian internet users, two main sources of online information are the social media site LINE and the online news portal detik.com (Kemp, 2020). LINE falls into the social media platform category due to its "timeline" feature, which resembles one found in Facebook, and which allows users to share status, voice messages, photos, videos, contact information, and location with other LINE users (Utami, 2016). According to the managing director of LINE, Ongki Kurniawan, around 90 million LINE users have been registered in Indonesia as of 
June 2016, and about 72 million of them are monthly active users (Bohang, 2016). This puts Indonesia within the top four countries in the world with the largest number of LINE users (Amalia, 2016). LINE users in Indonesia are dominated by the younger millennial generation (18-22 years old), which makes up as much as $41 \%$ of the country's total population (Bohang, 2016). On the other hand, detik.com is a news media portal that is successfully accessed by millions of Internet users every day in Indonesia (Putra, 2013).

Around half of all Internet users in Indonesia are 18-25 years old (APJII, 2014). At 88.5\% in 2018 (Haryanto, 2019), the large number of Internet users among Indonesian millennials implies an increase in the amount of information available to the public (Juditha, 2018). Yet not all of the information found on the internet is accurate, clearly sourced, and credible (Putra, 2013; Amalia, 2016). This diversity in the trustworthiness of online media increases the likelihood of the consumption of false information on social media or news portals, which may alter a person's memory of information (Fenn, Griffin, Uitvlugt, \& Ravizza, 2014). This can further lead to the creation of false memory, a phenomenon that occurs when a person's memory of an event contains incorrect information or misinformation (Loftus \& Hofmann, 1989).

False memory is a type of memory error, whereby an individual seems to remember an event, but their memory is distorted (Okado \& Stark, 2005). False memory can be caused by several factors, such as emotions (Kaplan, Van Damme, Levine, \& Loftus, 2016), suggestions (Van
Damme \& Smets, 2014), feedback (Zhang, Zhang, Luo, \& Geng, 2016), and the source and media of information (Fenn et al., 2014). False memory appears in various forms, including as modifications in the context of memory (e.g., believing that one has witnessed an event) or changes in the content of the memory itself (e.g., believing that a criminal carried a gun instead of a knife) (Okado \& Stark, 2005). One approach that has often been used to help explain how false memory is generated is the misinformation effect (Zhu, Chen, Loftus, Lin, \& Dong, 2013), which occurs when one remembers misinformation details as part of the actual information (Calvillo, 2014). False memory is believed to occur due to inconsistencies between the memory of the actual event and the presence of misinformation about the event (Calvillo, 2014). In addition, false memory may also be influenced by the source of information, as past research had shown that statements consisting of misinformation will produce more false memories when the source of information is a person with more knowledge than when the source is a person who has little understanding of a topic or event (Smith \& Ellsworth, 1987).

When applied within the context of obtaining information from a media source, several factors determine how misinformation presented by the media can affect false memory, including media types and media credibility (Fenn et al., 2014), emotions prompted by the information (Porter et al., 2010), and language (Mickes et al., 2013). With regard to media credibility, a previous study found that the lower the credibility of the media, the lower the possibility that misinformation 
will lead to false memory ( $\mathrm{Zhu}$, Chen, Loftus, Lin, \& Dong, 2010). Media information taken from the Internet can be considered credible when it lists its information sources. By contrast, media information is not considered credible when its statements are inaccurate, contain gossip content, and have no clear source (Mickes et al., 2013). Previous studies on the credibility of social media and news portals as a source of information in relation to false memory have generated conflicting results. Fenn et al. (2014) sought the influence of Twitter on false memory and found that false information displayed through Twitter had low credibility, thus decreasing the occurrence of false memory. On the other hand, research conducted by Mickes et al. (2013) suggested that news (posts) on social media has a gossipy nature and illustrates the production of spontaneous thought, implying that the information is easier to integrate with existing memories and thus increases the prevalence of false memory. The difference in results between these two studies shows that the credibility of social media as a source of information remains inconsistent.

Furthermore, there exists a possibility that the different types of social media examined in the two aforementioned studies may have lead to contradictory results. Mickes et al. (2013) used the social media site Facebook, while the work of Fenn et al. (2014) employed Twitter. This may indicate that the type of social media investigated affects the credibility of information media and will determine the likelihood of false memory. Variations in the social media platforms used in past research suggest that the results may not necessarily be generalized to other forms of social media, highlighting the need for further research on other types of social media. Limitations in the types of social media used in prior studies prompted our interest in examining other types of social media and comparing them with information obtained from other media.

In addition to variations in the types of media of information, the language used in different media also affects false memory. Information presented in social media is inseparable from its language. Therefore, testing false memory related to social media presents a unique challenge, because it is bound by the influence of the style of language. In social media, informal language tends to be used, whereas in experimental settings, formal language is more common (Fenn et al., 2014). Mickes et al. (2013) indicates that the use of informal language enhances true memory, and as the language used in social media is one commonly used to communicate in daily life, it is possible that the misinformation spread through the informal language of social media may be more easily accepted as the truth. It follows that misinformation presented through social media is more easily integrated into existing memories and leads to false memory (Fenn et al., 2014), which may be due to the informal language used in social media. Yet contrary to Mickes et al.'s (2013) suggestion, Fenn et al. (2014) found no difference in false memory with the informal or formal language used in social media. The difference in the results of the two studies suggests that it may be necessary to simultaneously examine the influence of media credibility and language, to ascertain whether an interaction 
between credibility and the language used in the media can influence false memory.

Given the high degree of use of social media in recent times, the current study aims to test whether misinformation received through a social media site like LINE affects false memory differently from misinformation obtained from nonsocial media, especially online news portals. While previous studies have found that people tend to create false memory from misinformation presented through the media, the study of the role of social media in false memory remains limited in Indonesia. Moreover, no past study has examined the simultaneous influence of media credibility and false memory. As such, to examine the effects of media credibility and language on false memory, the current study uses Indonesians as participants. This study focuses on two different sources of information, which have different levels of credibility and where different types of language predominate. LINE was investigated in this study as social media, with low credibility and a predominantly informal language, while detik.com serves as a source that has high credibility and that uses formal language. LINE is considered to be low in credibility because the information contains gossip and is widespread, making it difficult to distinguish accurate from inaccurate information. On the other hand, detik.com was chosen as a highcredibility medium because it contains news information with quotes from experts and reliable sources.

Based on the above explanations, the current study hypothesizes that: H1: The group with misinformation delivered through the news portal detik.com would have greater confidence in misinformation and a greater prevalence of false memory than the group given misinformation through LINE. H2: Media information with more formal language would produce greater confidence in the misinformation provided and greater false memory than media information with informal language. H3: There would be an interaction between media credibility and the language used in the information media in the context of false memory.

\section{Methods}

Sample. 106 college students aged 18-25 $(M=19.24, S D=0.97)$ participated in this study. The participants consisted of 29 males $(27.35 \%)$ and 77 females (72.65\%). Each participant was randomly placed into one of four groups, namely, LINE-Formal Language $(\mathrm{n}=28)$; LINE-Informal Language $(\mathrm{n}=26)$; detik.com-Formal Language ( $\mathrm{n}=25)$; and detik.comInformal Language $(\mathrm{n}=27)$. In each treatment group, the number of female participants was greater than males. Participants were acquired through convenience sampling technique and recruited using an online form (Google Form).

Research Design. This study used a 2 (media credibility) $\times 2$ (language) factorial design. Media credibility was manipulated by giving information through social media (LINE) and non-social media (detik.com). However, the language used in the media given as a source of information was additionally varied, with some being provided information in formal language and others in informal language. Adhering to the methods used by Fenn et 
al. (2014), false memory was measured using a confidence test.

\section{Measures and apparatus}

Image Clips. A series of image clips was presented during the encoding stage of the experiment (see procedure section). For the clips, a compilation of 30 pictures taken from the movie "Teman Lama" on YouTube was used. The sequence of images informed participants about a kidnapping event. The movie "Teman Lama" was chosen for its low number of viewers, making it unlikely that participants would be familiar with the video.

General Self-Efficacy Scale. The General Self-Efficacy Scale (GSES-12), which was developed by Bosscher and Smit (1998) and adapted into Indonesian, was used in the distraction stage of the experiment (see procedure section) to prevent participants from correctly guessing the true objective of the experiment and from rehearsing the information provided in the clips shown in the previous stage of experiment. The GSES-12 contains 15 statement items scored using a four-point scale, ranging from 1 (strongly agree) to 4 (strongly disagree).

Misinformation. Misinformation was given through information-related statements about the previously presented images in LINE-style and detik.com-style designs (see procedure section). In the LINE group, the information was displayed in the form of commentary bubbles in LINE's timeline feature, while in detik.com group, the information was displayed as an online news column (see Figures 1a and 1b). Misinformation was displayed on a screen using a projector.

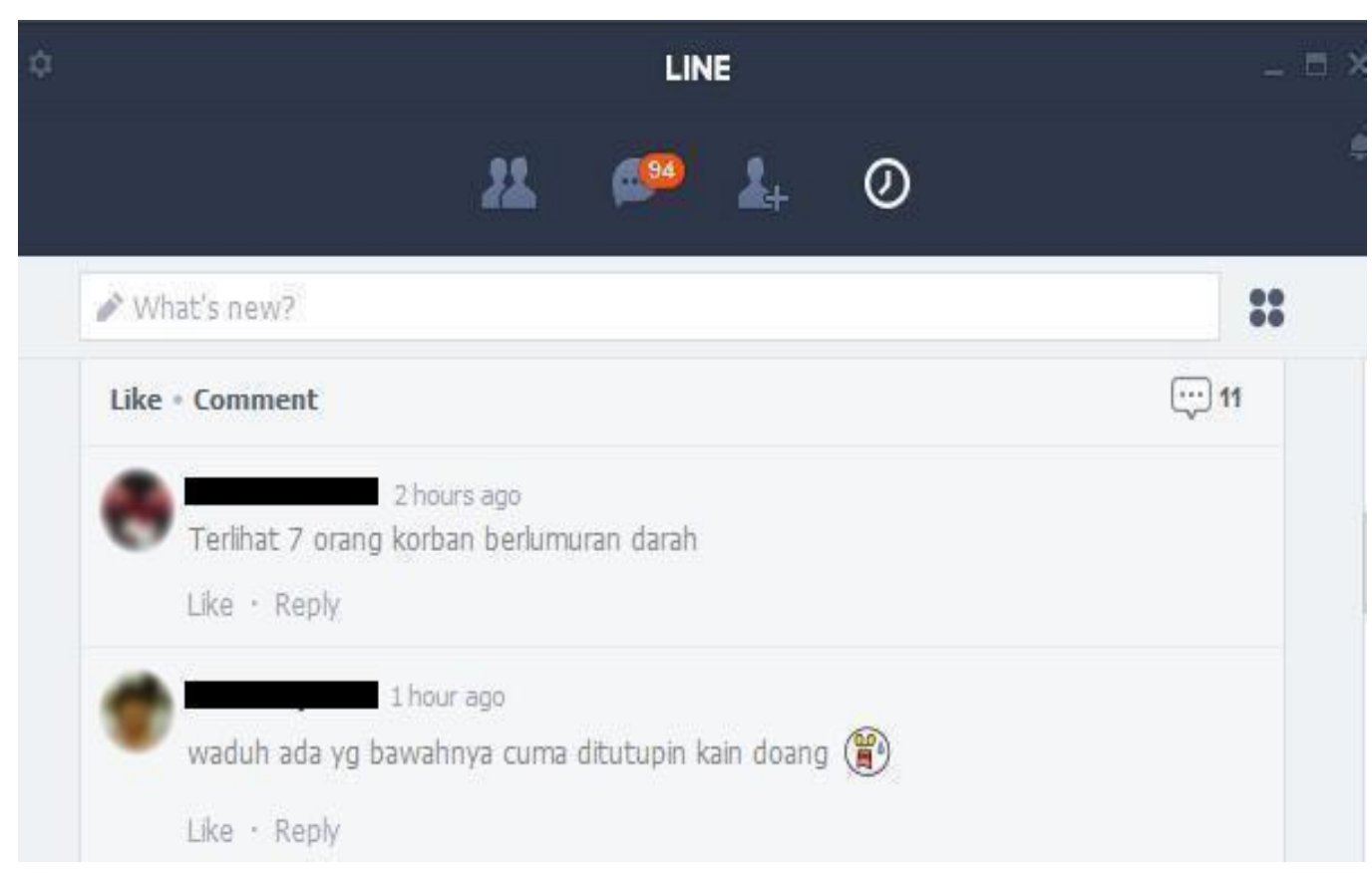

Figure 1a. Example of information in the timeline of the LINE 


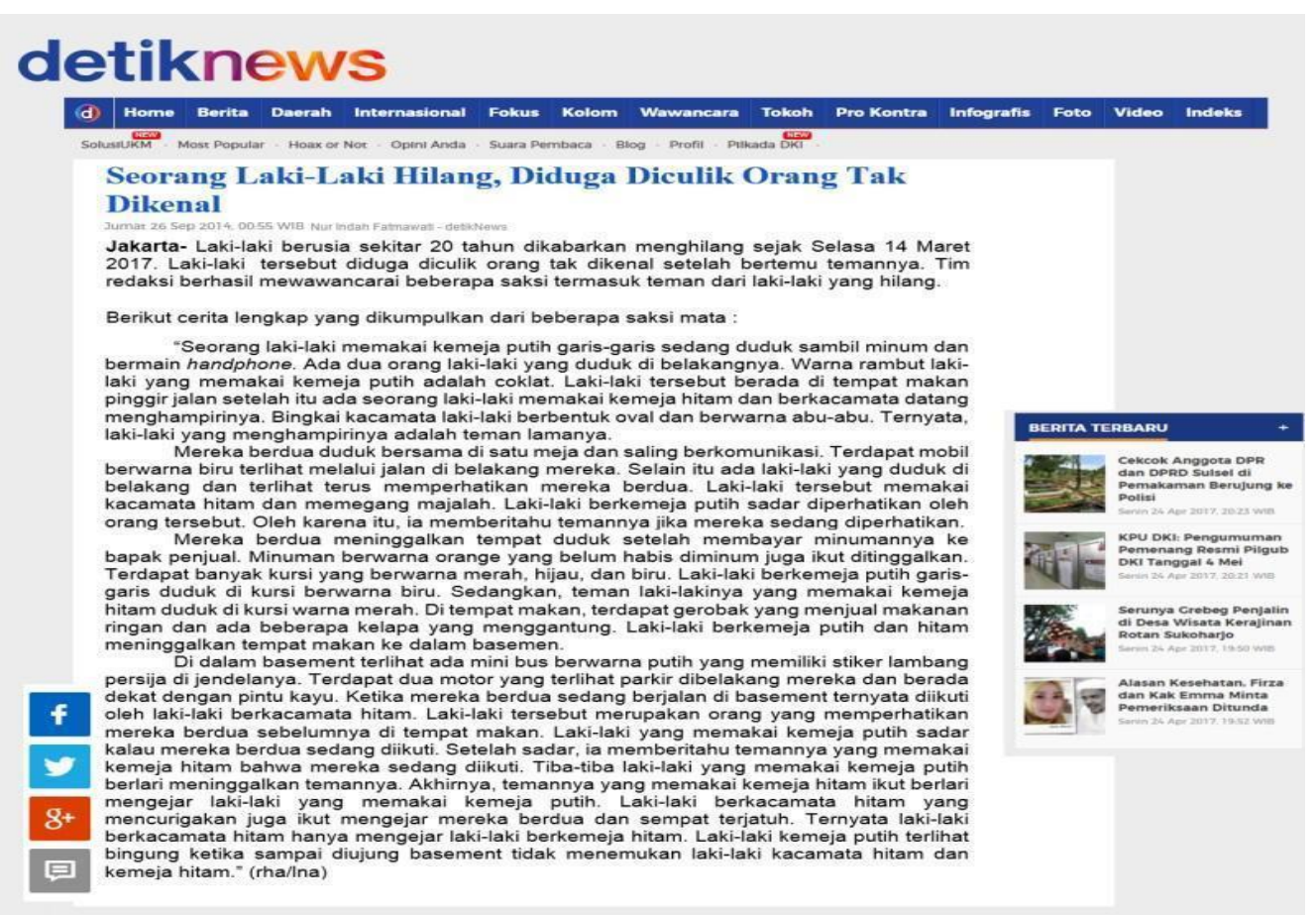

Figure $1 \mathrm{~b}$. Example of information in online news column

Confidence Test. False memory measurement was adopted from the method used by Fenn et al. (2014), in which false memory was operationally defined as how confident individuals feel about the accuracy of the information given to them. The confidence test contained 20 items, with 10 items measuring false memory and 10 items measuring true memory. Specifically, the 10 items intended to measure false memory consisted of 5 items of misinformation derived from the images and 5 items of misinformation unrelated to the images, while the 10 items for measuring true memory were comprised of 5 items of correct information derived from the images and 5 items of correct information derived from the social media display. An example of an item of misinformation was "Inside the basement there was a white minibus with a Persija sticker on the window," but in the original image picture, no such sticker was shown. The participants were asked to respond to each item based on their own memories of the images given in the encoding stage. For each item, participants rated their confidence in whether the information was presented in the pictures or images. Answers were given on a five-point scale, ranging from 1 (very unsure) to 5 (very sure). The results of the confidence test consisted of two scores, namely true memory score and false memory score, with a score range of 10-50 for each of the two scores. Higher scores indicate higher certainty in each type of memory.

\section{Procedure}

\section{Pilot study phase}

Prior to the experiment, a pilot study was conducted on a group of university students to ensure that the credibility of the social media platform chosen for the experiment was in line with the objective 
of the study. The pilot study also served to ascertain that the language styles used in the experimental procedure were indeed perceived as formal and informal language. According to the results of the pilot study, the participants rated detik.com as a more credible media source than LINE, and the language categories were deemed appropriate.

\section{Experiment phase}

The experiment was conducted in groups, inside a classroom. Seating position, projector, and room temperature were held constant. Prior to the start of the experiment, participants were asked to complete informed consent forms. Our experiment followed the steps performed by Fenn et al. (2014). All participants followed the same experimental stages: encoding, distraction, misinformation, and confidence test (see Figure 2). During the encoding stage, all participants were shown a series of 30 images. Each image was displayed for 5 seconds on a projector screen in the classroom. All participants were asked to sit and concentrate while examining the pictures. Credibility of the source was held constant by informing each participant that the series of images in the encoding stage was a re-creation of a real event involving a kidnapped person that happened three years prior (see Figure 3).

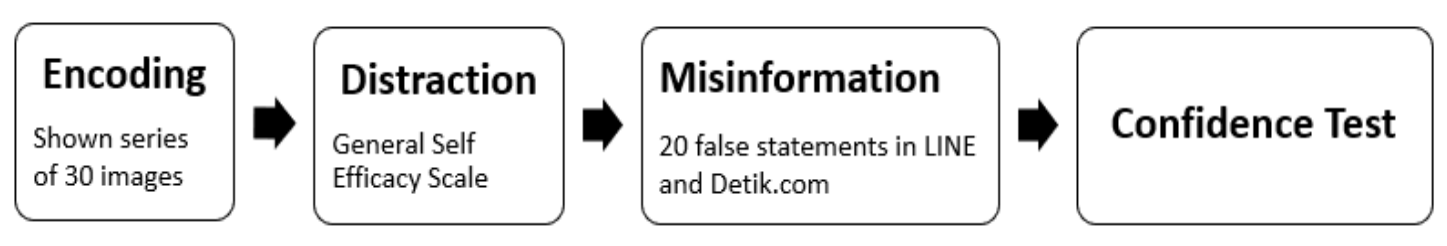

Figure 2. Experiment phase stages
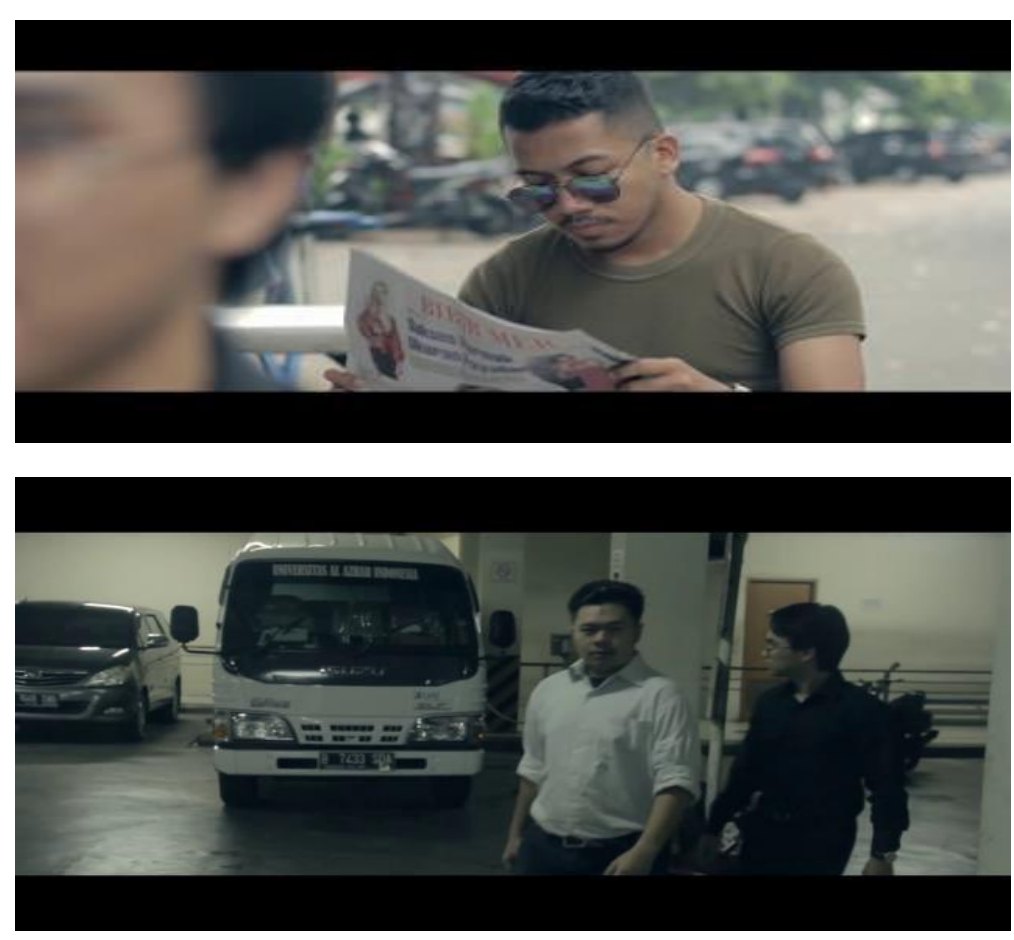

Figure 3. Example of picture that shown on encoding stage 
Subsequently, participants performed the second phase of the experiment, which was the distraction stage. At this stage, participants filled out the General Self Efficacy Scale (GSES-12) questionnaire. The distraction was performed to reduce the likelihood that the participants would rehearse the information provided in the previously encoded images. Following completion of the second stage, participants then began the third stage, which encompassed presenting participants with the intended information and misinformation. More specifically, participants were given 20 statements related to the previously displayed image sequence in the style of either LINE or the detik.com design, depending on the experimental group the participants were assigned to. Participants in the LINE group examined the information as a LINE timeline post and its commentary bubbles (see Figure 1a), while participants in the detik.com group examined the information in the form of online news columns (see Figure 1b). Both participants in the detik.com group and LINE group were informed that information on the kidnapping was derived from an eyewitness of the event, to ensure that participants would have the same level of trust in the information presented.

In the fourth or final stage of the experiment, participants were instructed to fill out a confidence test based on their own beliefs about the images presented through LINE or detik.com. The confidence test was aimed at measuring the formation of false memory. Before the experiment was completed, a manipulation check was conducted, in which participants were asked to determine whether they had seen the sequence of images during the encoding stage.

\section{Results}

A two-factor analysis of variance (ANOVA) was conducted to compare the false memory in each treatment group. We used IBM SPSS version 22 for Windows to analyze the statistical data.

True memory. Analyses of true memory showed no significant effect for media credibility $F(1,102)=0.522, p=0.472$; media language, $F(1,102)=0.825, p=0.366$; or interaction between media credibility and language, $F(1,102)=0.019, p=0.892$. All factors, including media credibility, media language, and interaction between media credibility and media language, were found to have no significant effect on true memory.

False memory. Two-factor analysis of variance in false memory shows a significant main effect for media credibility, $F(1$, 102) $=4.86, p=0.03, \eta 2=0.04 ;$ no significant effect for media language, $F(1,102)=0.14, p=0.70$; and no significant interaction between media credibility and language, $F(1,102)=0.16, p=0.69$. From this result, we conclude that $\mathrm{H} 1$ is supported, but $\mathrm{H} 2$ and $\mathrm{H} 3$ are not. The significant effect of media credibility on false memory shows that the confidence level is greater in the detik.com group than in the LINE group.

\section{Discussion}

This study aimed to examine the influence of credibility and language in Internetbased media on false memory. The result showed that media credibility significantly affects false memory. In this study, participants in the detik.com group were 
Table 1.

Means and Standard Deviations of True Memory $(N=106)$

\begin{tabular}{lcccccccccc}
\hline \multirow{2}{*}{$\begin{array}{c}\text { Media } \\
\text { Credibility }\end{array}$} & \multicolumn{9}{c}{ Formal } & \multicolumn{9}{c}{ Language } \\
\cline { 2 - 12 } & $n$ & $M$ & $S D$ & $n$ & $M$ & $S D$ & $n$ & $M$ & $S D$ \\
\hline Detik.com & 25 & 35.12 & 4.82 & 27 & 34.44 & 3.45 & 52 & 69.56 & 8.27 \\
LINE & 28 & 34.61 & 4.71 & 26 & 33.69 & 4.91 & 54 & 68.30 & 9.62 \\
Total & 53 & 69.73 & 9.53 & 53 & 68.13 & 8.36 & 106 & 137.8 & 17.89 \\
\hline
\end{tabular}

Note: score range: $10-50$

Table 2.

Means and Standard Deviations of False Memory $(N=106)$

\begin{tabular}{|c|c|c|c|c|c|c|c|c|c|}
\hline \multirow{3}{*}{$\begin{array}{c}\text { Media } \\
\text { Credibility }\end{array}$} & \multicolumn{9}{|c|}{ Language } \\
\hline & \multicolumn{3}{|c|}{ Formal } & \multicolumn{3}{|c|}{ Informal } & \multicolumn{3}{|c|}{ Total } \\
\hline & $n$ & $M$ & $S D$ & $n$ & $M$ & $S D$ & $n$ & $M$ & $S D$ \\
\hline Detik.com & 25 & 23.20 & 6.11 & 27 & 23.19 & 5.68 & 52 & 46.36 & 11.79 \\
\hline LINE & 28 & 20.39 & 5.35 & 26 & 21.23 & 5.05 & 54 & 41.62 & 10.39 \\
\hline Total & 53 & 43.59 & 11.46 & 53 & 44.42 & 10.72 & 106 & 87.98 & 22.18 \\
\hline
\end{tabular}

more confident in the information received and had greater false memory than the LINE group. However, no significant effect of language and no significant interaction effect between media credibility and language were found on false memory.

The current results showed that media credibility influences false memory, in that the greater the credibility of the media, the greater the false memory appears. In this study, the detik.com news portal is considered to have a higher credibility than LINE, leading readers to believe the misinformation presented on detik.com more than that on LINE. Tseng and Fogg (1999) explained that the measurement of credibility depends on two key elements, namely trustworthiness and expertise. The dimension of trustworthiness, which is presumed to be well-intentioned, truthful, and unbiased, refers to the perceived goodness or morality of the source. Expertise, on the other hand, alludes to the perceived knowledge and skill of a source, and is characterized by knowledgeability, experience, and competence. When viewed from the dimensions of trustworthiness and expertise, then, it is conceivable that detik.com is superior to LINE in these two decisive factors because information found in detik.com is typically sourced from an expert and therefore believed to be more credible than information obtained from a more questionable source like LINE.

Moreover, the difference in the perceived credibility between detik.com and LINE may also be attributable to the nature of information presented in the two platforms. It is well known that detik.com generally presents information in the form of news, and news portals are considered more credible because they contain citations and their information comes from 
experts (Mickes et al., 2013). Similarly, Flanagin and Metzger (2000) found that the information submitted by news and reference-based media have greater media credibility than entertainment-based and commercial media. Taken together, this may further strengthen the argument that detik.com has greater credibility and reliability than LINE, which generally presents information for the purposes of entertainment.

The average score for false memory was higher in participants who were given the information through detik.com than those who received it through LINE. This means that participants in the detik.com group tend to have a greater belief in misinformation than the participants in the LINE group. This explanation is in accordance with Echterhoff, Hirst, and Hussy (2005) and Fenn et al. (2014), who found that the lower the credibility of the media containing misinformation, the less are the false memories, and vice versa. This may have occurred because participants in the LINE group trusted the information they received less than participants in the detik.com group did, which would align with Fenn et al.'s (2014) suggestion that one of the important factors that influence false memory is the credibility of the medium in which it is encountered. Media credibility is important for determining the relative believability of particular forms of communication, such as newspaper or television. The credibility of Internet-based media can be assessed, because new research about web credibility from the traditional perspectives of source, message, and media credibility can incorporate the lessons learned from past research (Metzger, Flanagin,
Eyal, Lemus, \& Mccann 2003).

The present study also found that media credibility had no significant effect on true memory. According to Fenn et al. (2014), the absence of differences in true memory between groups indicates that participants consistently paid attention to the stimulus and carefully encoded the information. The fact that the mean score for true memory is greater than the score for false memory suggests that participants paid close attention to the misinformation given by the researcher instead of randomly guessing the answer in the confidence test.

This study additionally found that language had no effect on false memory, which is consistent with the findings of Fenn et al. (2014). The absence of this effect may be because the language used at both the news portal detik.com and LINE is equally easy to read. This is in line with the suggestion of Mickes et al. (2013), who propose that the headlines on a news portal, in their case $\mathrm{CNN}$, are easier to remember, while Facebook content is easily remembered because it is written in a casual (informal) style and without any quotations from experts. Based on this explanation, it is possible to conclude that the absence of a difference between the formal or informal language used in the news portal and LINE, respectively, may be due to the fact that both styles of language are easy to read and to understand.

Further, this study found no signify-cant interaction between media credibility and language in the media. In other words, the credibility of the media was not found to depend on the type of language used. This absence of interaction could be 
caused by participants' prior perceptions of the credibility of the media. Mitra, Wright, and Gilbert (2017) examined language factors as predictors of media credibility, finding that features of the language used in social media, such as subjectivity, modalities, negations, exclusions, conjunctions, quotes, hedges, boosters, evidentiality, anxiety, positive emotions, and negative emotions could affect the level of credibility perceived by participants. As a consequence, more than categorizing the language type into formal or informal, deeper linguistic analysis is also needed to create conditions where participants' perceptions of media credibility matches the syntax used.

This study had several limitations. First, although the experimental procedure employed in the current study was adopted from Fenn et al.'s (2014) research, it was not an exact replication. In particular, the current study excluded one step in the original study that was administered immediately after the confidence test, namely an assessment of participants' attention to and participants' trust in the information provided. Such measurements could have potentially provided a more thorough picture about whether false memory did indeed occur. Another limitation stemmed from the news portal's visualization. The delivery styles, news quotes, and informal languages constructed for this experiment appeared somewhat artificial to our participants. In addition, as mentioned above, the features of language studied by Mitra et al., (2017), were not further examined in our study, thus possibly minimizing the interaction between credibility and language in the media.

\section{Conclusions}

We conclude that there is a significant effect of media credibility on the formation of false memory. However, the language of media and the interaction between media credibility and language was not found to significantly affect false memory. Based on our findings, we recommend that individuals should be more careful in reading the news, even when the media source is considered credible, because such news source has been shown to have a greater potential to create false memory. Furthermore, the vast and growing number of internet users requires a more critical approach to reading information and should not focus on one source alone. The results should also encourage social media users to be more responsible and cautious in spreading information in order to avoid deception. This responsibility is even greater for those who spread information through a type of media that is considered more credible (e.g., news portals), because readers are more likely to trust the information that is presented.

\section{Suggestions}

Research studies about credibility and false memory are still limited in Indonesia and need to be increased. In this study, the appearance of the detik.com news portal such as the style of news delivery, news quotes, and the language use look little different from online news in general with the result of that, for future research is advised to make the appearance of the media credibility more similar to what people find on the internet. 


\section{Funding}

This study was not funded by any funding program.

\section{Authors' contribution}

DM conducted literature study, analysed the result, refined conclusions, and revised the manuscript. IMH, LNA, MDM conducted literature study, conducted data gathering, and ran statistical analysis. ESS proofread and revised the manuscript.

\section{Conflict of interest}

There is no conflict of interests in regards to this research

\section{Orchid id}

Dewi Maulina

http://orcid.org/0000-0003-0497-3355

Ishaq Mahmudil Hakim

https://orcid.org/0000-0002-2751-1949

Ladayna Nurul Arasy

https://orcid.org/0000-0003-1767-0409

Marsa Dhiya Millatina

https://orcid.org/0000-0001-7264-4479

Ermanda Saskia Siregar

http://orcid.org/0000-0001-6571-7844

\section{Reference}

Amalia, E. I. (2016). Jumlah pengguna line di indonesia terbanyak keempat di dunia]. Retrieved from: www.mediaindonesia.com/news/read/ 64899 on March 122017.

Asosiasi Penyedia Jasa Internet Indonesia (APJII). (2014). Profil pengguna internet Indonesia 2014. Jakarta: Puskakom UI.

Bohang, K. (2016). Di indonesia, jumlah pengguna line pepet Facebook. Retrieved from http://goo.gl/iXMmxd on March 122017.

Bosscher, R. J., \& Smit, J. H. (1998). Confirmatory factor analysis of the General Self-Efficacy Scale. Behaviour
Research and Therapy, 36, 339-343. doi: 10.1016/S0005-7967(98)00025-4

Calvillo, D. P. (2014). Individual differences in susceptibility to misinformation effects and hindsight bias. The Journal of General Psychology, 141(4), 393-407. doi: $\underline{10.1080 / 00221309.2014 .954917}$

Echterhoff, G., Hirst, W., \& Hussy, W. (2005). How eyewitnesses resist misinformation: Social postwarnings and the monitoring of memory characteristics. Memory \& Cognition, 33(5), 770-782.

Fenn, K., Griffin, N., Uitvlugt, M., \& Ravizza, S. (2014). The effect of Twitter exposure on false memory formation. Psychonomic Bulletin \& Review, 21(6), 1551-1556. doi: 10.3758/s13423-0140639-9.

Flanagin, A., \& Metzger, M. (2000). Perceptions of internet information credibility. Journalism \& Mass Communication Quarterly, 77(3), 515-540. doi: $\underline{10.1177 / 107769900007700304}$

Haryanto, A. T. (2019). Pengguna internet Indonesia didominasi milenial. Retrieved from: https://inet.detik.com/telecommunicati on/d-4551389/pengguna-internetindonesia-didominasi-milenial on August 252020.

Juditha, C. (2018). Interaksi komunikasi hoax di media sosial serta antisipasinya. Jurnal Pekommas, 3(1), 31-44. doi: $\underline{10.30818 / j p k m .2018 .2030104}$

Kaplan, R. L., Van Damme, I., Levine, L. J., \& Loftus, E. F. (2016). Emotion and false memory. Emotion Review, 8(1), 813.

Kemp, S. (2020). Digital 2020: Indonesia DataReportal - Global Digital Insights. Retrieved from: https://datareportal.com/reports/digita 
1-2020-indonesia on August 182020.

Loftus, E. F., \& Hoffman, H. G. (1989). Misinformation and memory: The creation of new memories. Journal of Experimental Psychology: General, 118, 100-104. doi: 10.1037/0096$\underline{3445.118 .1 .100}$

Metzger, M., Flanagin, A., Eyal, K., Lemus, D., \& Mccann, R. (2003). Credibility for the 21st Century: Integrating perspectives on source, message, and media credibility in the contemporary media environment. Annals of The International Communication Association, 27(1), 293-335. doi: 10.1080/23808985.2003.11679029.

Mickes, L., Darby, R. S., Hwe, V., Bajic, D., Warker, J. A., Harris, C. R., \& Christenfeld, N. J. (2013). Major memory for microblogs. Memory $\mathcal{E}$ Cognition, 41(4), 481-489. doi: 10.3758/s13421-012-0281-6.

Mitra, T., Wright, G. P., \& Gilbert, E. (2017). A Parsimonious Language Model of Social Media Credibility across Disparate Events. Proceedings of the 2017 ACM Conference on Computer Supported Cooperative Work and Social Computing - CSCW 17. doi: 10.1145/2998181.2998351

Okado, Y., \& Stark, C. E. (2005). Neural activity during encoding predicts false memories created by misinformation. Learning $\mathcal{E}$ Memory, 12(1), 3-11. doi: $\underline{10.1101 / 1 \mathrm{~m} .87605}$

Porter, S., McDougall, A., Bellhouse, S., Brinke, L. Ten, \& Wilson, K. (2010). A prospective investigation of the vulnerability of memory for positive and negative emotional scenes to the misinformation effect. Canadian Journal of Behavioural Science, 42(1), 55-61. doi: $\underline{10.1037 / \mathrm{a} 0016652}$

Putra, A. W. (2013). Faster access to news on windows phone with detik.com's official application. [Akses berita lebih cepat di windows phone dengan aplikasi resmi detik.com]. Retrieved From: https://teknojurnal.com/aksesberita-lebih-cepat-di-windows-phonedengan-aplikasi-resmi-detik-com/ on March 122017.

Smith, V. L., \& Ellsworth, P. C. (1987). The social psychology of eyewitness accuracy: Misleading questions and communicator expertise. Journal of Applied Psychology, 72(2), 294.

Tseng, S., \& Fogg, B. J. (1999). Credibility and computing technology. Communications of the ACM, 42(5), 39-44. doi: 10.1145/301353.301402

Utami, K. D. (2016). Pemanfaatan jejaring sosial line pada komunikasi kelompok Kos Putri "Naomi." Jurnal Ilmu Komunikasi UPNYK, 14(1), 48-56.

Van Deursen, A., \& Van Dijk, J. (2013). The digital divide shifts to differences in usage. New Media $\mathcal{E}$ Society, 16(3), 507526. doi: $\underline{10.1177 / 1461444813487959}$

Van Damme, I., \& Smets, K. (2014). The power of emotion versus the power of suggestion: Memory for emotional events in the misinformation paradigm. Emotion, 14(2), 310-320. doi: 10.1037/a003462

Zhang, F., Zhang, X., Luo, M., \& Geng, H. (2016). The effects of feedback on memory strategies of younger and older adults. PLoS One, 11(12). doi: 10.1371/journal.pone.0168896

Zhu, B., Chen, C., F. Loftus, E., Lin, C., \& Dong, Q. (2010). Treat and trick: A new way to increase false memory. Applied Cognitive Psychology, 24(9), 1199-1208. doi: 10.1002/acp.1637

Zhu, B., Chen, C., Loftus, E. F., Lin, C., \& Dong, Q. (2013). The relationship between DRM and misinformation 
false memories. Memory $\mathcal{E}$ Cognition,

013-0300-2.

41(6), 832-838. doi: 10.3758/s13421- 